\title{
成層型ダム湖における濁水特性と 選択取水効果に関する事例的研究
}

\section{A CASE STUDY ON THE BEHAVIOR OF TURBIDITY CURRENT IN DAM RESERVOIRS AND SELECTIVE WITHDRAWAL METHOD}

\author{
堀出哲夫 1 - 陳飛勇 $2 \cdot$ 山下芳浩 $3 \cdot$ 東海林光 ${ }^{4}$ \\ By T. HOTTA, F.Y. CHEN, Y. YAMASHITA, H. SHOJI
}

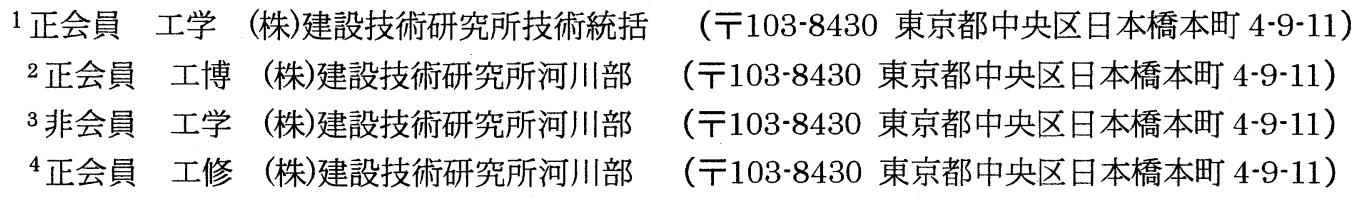

In this paper we present the behavior of turbidity current in stratified reservoirs. First, continuous calculations over 10years for two dams were conducted. The results suggest that the extension-period of high turbidity water depends on the flood discharge and the stratification condition of dam reservoirs. Then a trial study was conducted to find a critical parameter, which can be used to determine whether an extension-period of high turbidity water will be induced. Finally, the effect of selective withdraw, as a kind of countermeasures to reduce the extension-period of high turbidity water, were predicted. The results show that this countermeasure is useful when a flood discharge is not so large.

Key Words: Turbidity current, dam reservoir, discharge, stratification, and selective withdrawal

\section{1.はじめに}

我が国で，ダム貯水池の濁水現象が社会問題とな り始めたのは, 一ッ瀬ダム, 早明浦ダムなどでそれ らの現象が顕在化した昭和 40 年代半ばからである. それ以来, 電力中央研究所, 旧建設省土木研究所, 大学等で各種調査研究が行われ，現象の解明と各種 予測モデルの開発が行われた ${ }^{12)}$. さらに, それら技 術の実際ダム湖への適用が幅広く実施され，近年築 造されたダム貯水池では，有効な対策として選択取 水設備（表層取水設備含）が多く設置されている.

一方, 近年は従来の漁業被害や, 景観・浄水処理 被害等の視点に加え，生物生息環境への影響，流砂 系の総合土砂管理との関連などで，濁水長期化現象 への注目度が高まりつつある.そのため, 選択取水 に加え, 曝気, 流入端フェンス, バイパスなどの対 策が試行されてきたが 3)，一部の既設ダムでは，濁 水長期化現象の軽減及び防止を図るため, 既存の選 択取水設備のさらなる有効活用が緊急の課題となっ てきている.

土木研究所 ${ }^{2)}$ の検討では, 選択取水設備の運用に
ついて，大まかな運用方法を示したものの，一般化 が困難なこともあり, 洪水規模や発生時期, さらに 取水設備の形状や洪水吐の位置との関係を踏まえた 効果的な選択取水設備の運用方法について検討した 研究は殆ど見られない。また，成層期のダム運用は ダムの規模や濁水特性に関わらず，表層取水が一般 的となっている.

本研究はこのような状況を踏まえ, 数值シミュレ 一ションモデルを活用し，実用的な視点から様々な 洪水条件において, 成層型貯水池における濁水長期 化現象とその対策としての選択取水運用について検 討を行う.すなわち, 各種洪水の生起状況（規模 時期及び水温成層状況）と濁水長期化の関係の定量 化を試行し，選択取水が有効と考えられる中小規模 出水について, その効果の予測及び対応洪水規模の 限界の検討を行う。

\section{2.シミュレーションモデルの構築}

(1) モデルの構成

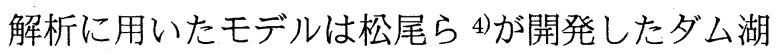


(1) A ダムにおける水温検証結果（H6）

ダムサイト
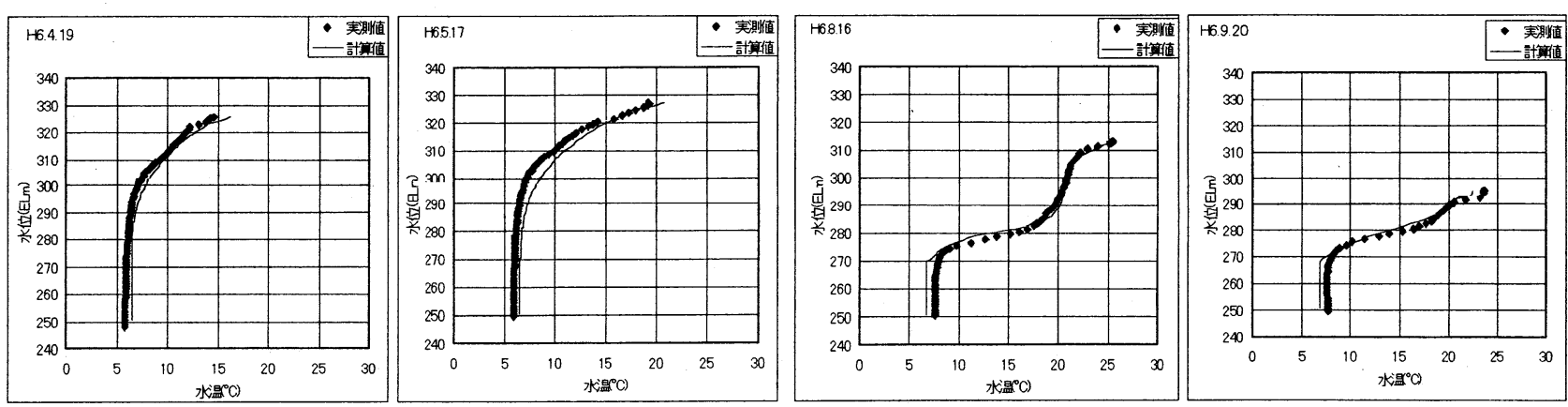

(2) 濁度鉛直分布の検証 (A ダム, H5.8.17 出水)

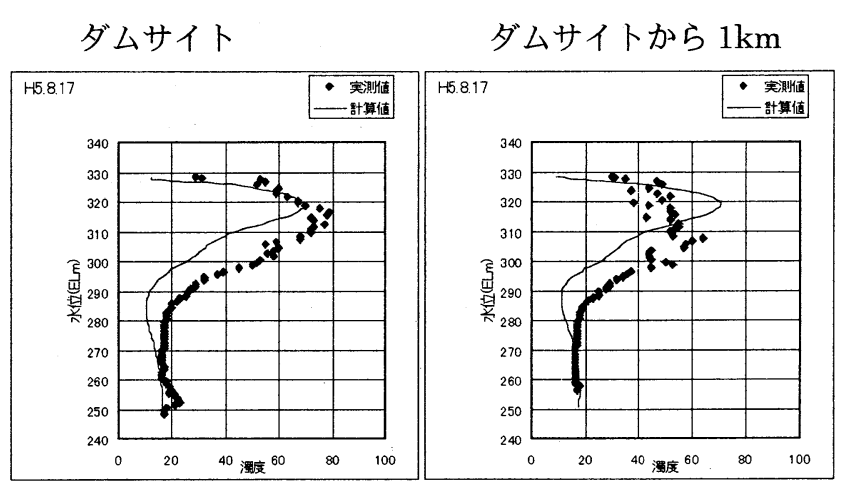

ダムサイトから $2.6 \mathrm{~km}$ ダムサイトから $4.2 \mathrm{~km}$

図-1 水温・濁度の検証計算結果

水理・水質モデルを参考にして作成したものであり， 鉛直 2 次元の水理・濁質モデル及び熱収支モデルか ら構成されている3),5)。

\section{（2）モデルの検証}

貯水池における濁水現象及びその対策効果を把握 するため,これら現象の再現性及び精度について検 討した。

本モデルは既にわが国の多数の貯水池に適用され， 様々な角度から検討が行われており、現地デー夕を よく再現することが示されている（例えば,文献 3 ),

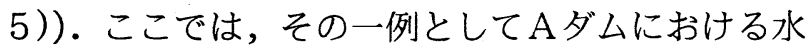
温・濁度の検証計算結果を図-1に示す.

図-11は，平成 6 年の貯水池内水温の計算值と実 測值の比較である.A夕゙ムは四国に位置するため, 春季から秋季にかけて強い水温躍層が形成される. 罒を見ると貯水池は 4 月から受熱期にはいり，8 月 には強固な水温躍層が形成されている.

図-12は, 平成 5 年 8 月に生起した洪水の計算值 と実測值の比較である.計算值は, 濁水の流入位置, ピーク值などを概ね再現できていることが分かる.

\section{3.濁水長期化現象と洪水流入条件の関係}

\section{（1）検討対象ダムの選定および流入河川の流況}

成層型ダムでの選択取水効果を検討するため, 検 討対象ダムは水深が比較的大きく, 年回転率が小さ いものから選定した. 対象ダムは, 最大水深が約 $110 \mathrm{~m}$ ，年平均回転率が 6 回/年である関東の $\mathrm{B}$ ダ 厶と, 最大水深が約 $60 \mathrm{~m}$, 年平均回転率が 5 回/年 である東北の C ダムである. 但し，放流設備の運用 ルールは, 我が国の他ダムで一般的に採用されてい る以下の 2 パターンとした。

- 平常時表層取水 (2 ダムとも).

- 洪水時では $\mathrm{B}$ ダムは中層（洪水期制限水位よ り $20 \mathrm{~m}$ 下）コンジット放流，Cダムは上層オ リフィス放流 (常満敷高). 但し, C ダムはオ 一ルサーチャージ方式であるため, 夏期の水 位低下時には洪水の相当量を貯留し，水位回 復を行うことがある。

検討対象期間は, $\mathrm{B}$ ダムの利水計算実施期間中の 最大出水 (S57.8.2 洪水, 日平均流量 $955 \mathrm{~m}^{3} / \mathrm{s}$ ) を含 


\begin{tabular}{|l|c|c|c|c|c|}
\multicolumn{7}{c}{ 表-1 ダム流入河川流況表 $\left(\mathrm{m}^{3} / \mathrm{s}\right)$} \\
\hline & 豊水 & 平水 & 低水 & 渴水 & 最大 \\
\hline B ダム & 19.86 & 15.57 & 11.79 & 9.25 & 277.0 \\
\hline Cダム & 15.80 & 7.19 & 4.00 & 2.09 & 189.5 \\
\hline
\end{tabular}

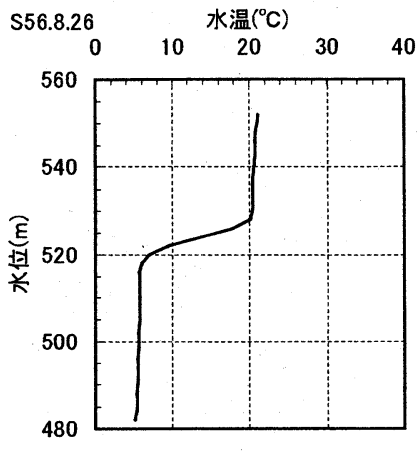

(a) Bダム

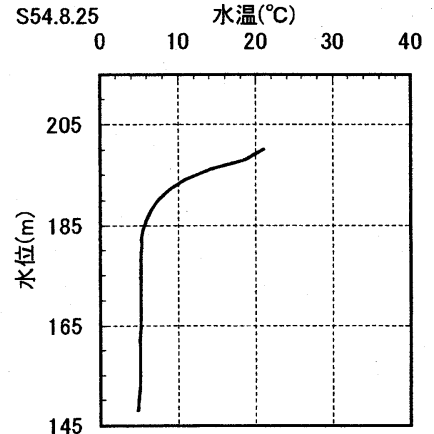

(b) Cダム

図-2 対象ダムの水温成層状況

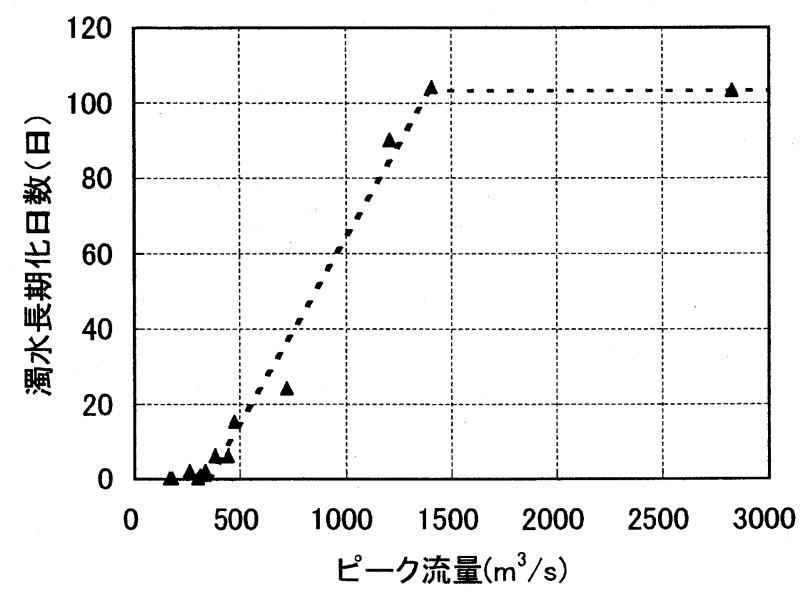

図-3 B ダムにおける洪水流量と濁水長期化日数の関係

む昭和 56 年〜平成 2 年の連続 10 ケ年, C ダムは昭 和 46 年〜平成 2 年の連続 20 ケ年とした. 検討対象 期間の流入河川の流況を表-1 に示す.

入力条件は流入, 放流口別の放流量, 気象条件, 流入水温・SS などである. 流入 SS は実測デー夕よ り得られた流量〜SS 濃度関係式より算定し，その粒 度組成は実測デー夕を用いて 4 分割とした。各粒径 の沈降速度はストークスの式より求めた。

\section{（2）水温成層状況}

検討対象とした 2 ダムの水温成層状況を図-2 に示 す. B ダムは 6 月下旬からコンジット部の放流口か ら放流を行い，貯水位を夏期制限水位まで低下させ るため, 明瞭な二次水温躍層が形成される.

一方，C ダムは常に表層放流を行うため，一次水 温躍層しか見られない.

（3）洪水時中層放流ダムにおける濁水長期化現象

$\mathrm{B}$ ダムの予測期間を対象に, 洪水ピーク流量と濁 水長期化日数との関係を図-3 に整理した.ここに， 濁水長期化日数は, 流入 $\mathrm{SS}$ 濃度が環境基準

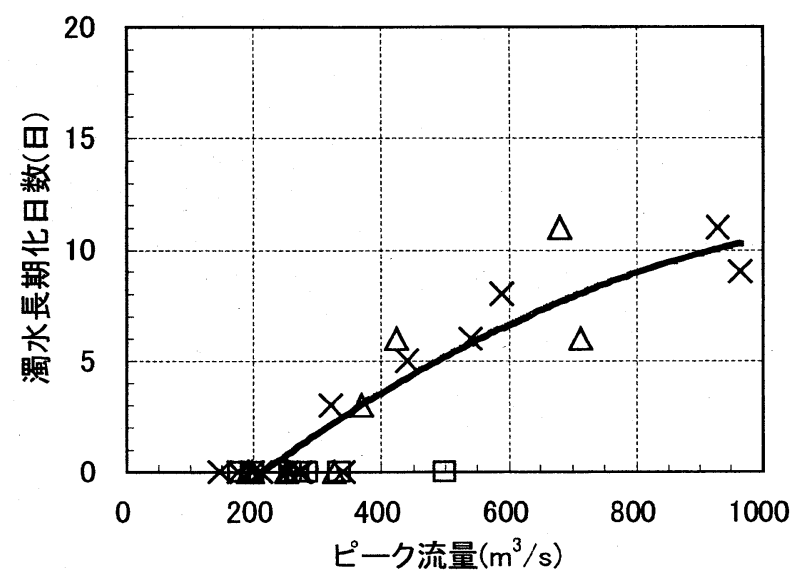

図-4 C ダムにおける洪水流量と濁水長期化日数の関係

（SS=25mg/l）以下であり，かつ放流 SS 濃度がこ れを越える日数である（放流濁水の目標值はダムの 流域特性や下流の社会環境を考慮して決定されるが, 本研究では便宜上, 環境基準値を指標として用いた)。

図-3から，濁水長期化現象は洪水ピーク流量が約 $300 \mathrm{~m}^{3} / \mathrm{s}$ を越える場合に見られることがわかる. 洪 水流量が $300 \sim 1400 \mathrm{~m}^{3} / \mathrm{s}$ では, 流量の増加に伴って 濁水長期化日数が増加するが, $1400 \mathrm{~m}^{3} / \mathrm{s}$ を越えると, あまり変化は見られない。これは，ある程度以上の 洪水では $\beta$ ( $\beta$ は, 洪水流入総量と洪水発生前の夕゙ 厶容量の比である.) が 1 以上となり, ダム湖の貯留 水が洪水による流入水と入れ替わるためである.な お，B ダムは流域に烟地が広く分布しており，流入 濁質量は非常に多い。

\section{（4）常時表層放流ダムにおける濁水長期化現象}

C ダムにおける濁水長期化現象を図-4に整理する. ここに, 三角形で示しているのは流量ピークが二つ 以上である洪水 (いわゆる 2 山洪水), 正方形は貯水 池水位が低下しており, 洪水のほぼ全量を貯留する ことによって水位回復を行っている場合である。 

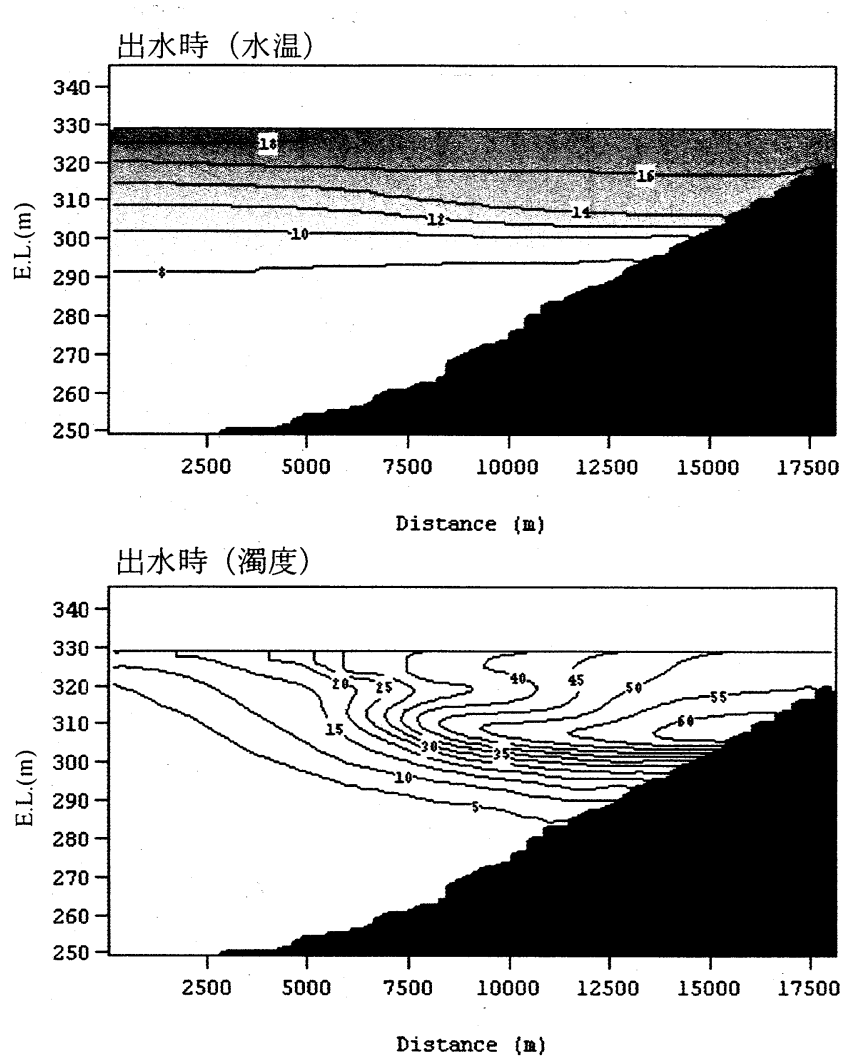

出水後 6 日 (水温)

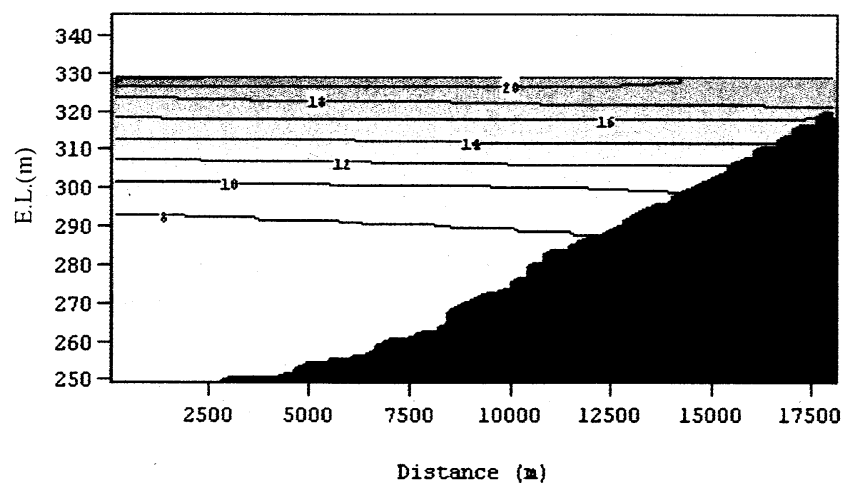

出水後 6 日（濁度）

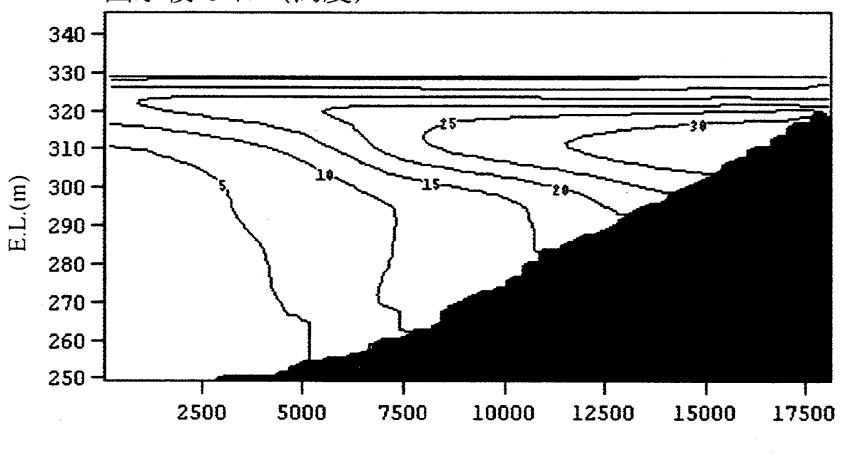

Distance (m)

(1)小規模出水による濁度分布 $(\beta=0.2)$
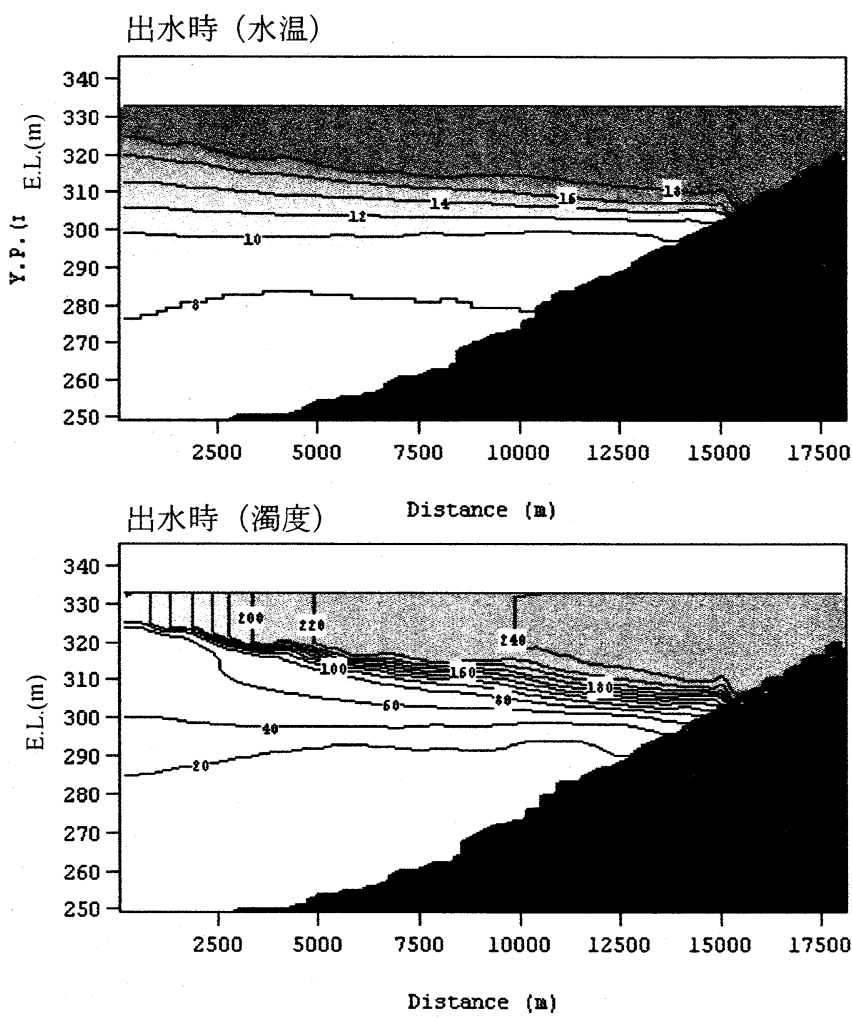

出水後 3 日（水温）
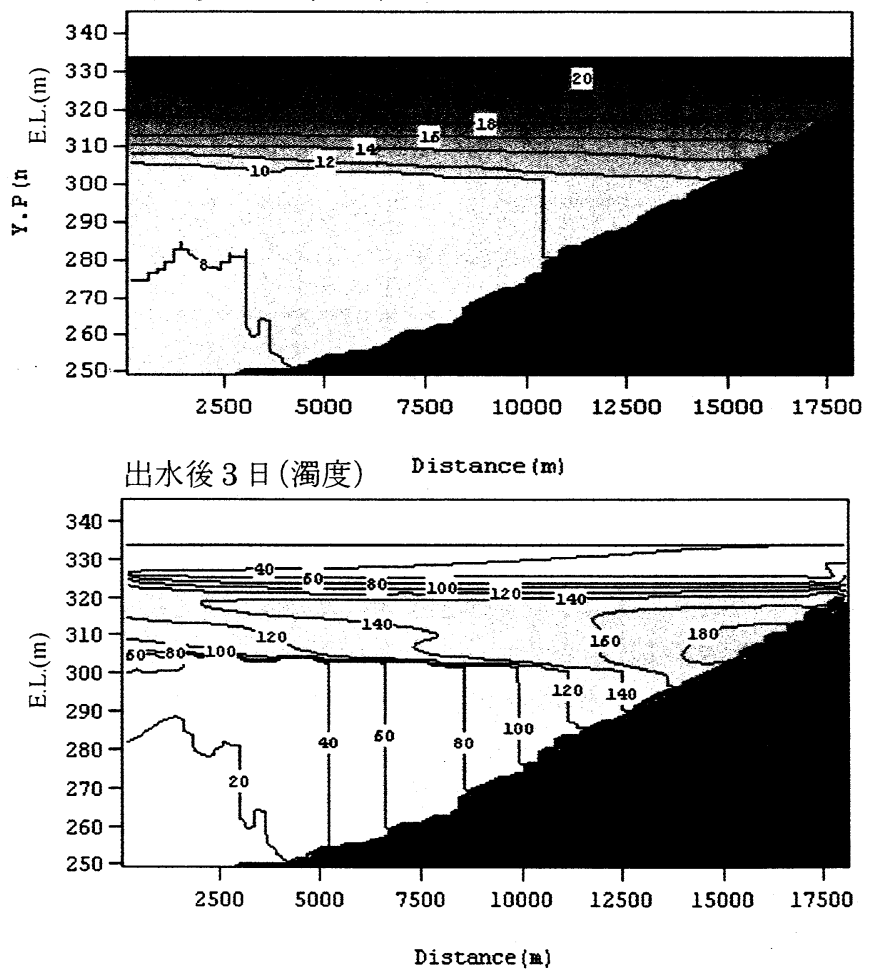

(2)中規模出水による濁度分布 $(\beta=0.9)$

図-5 中小規模出水による貯水池内濁水挙動 


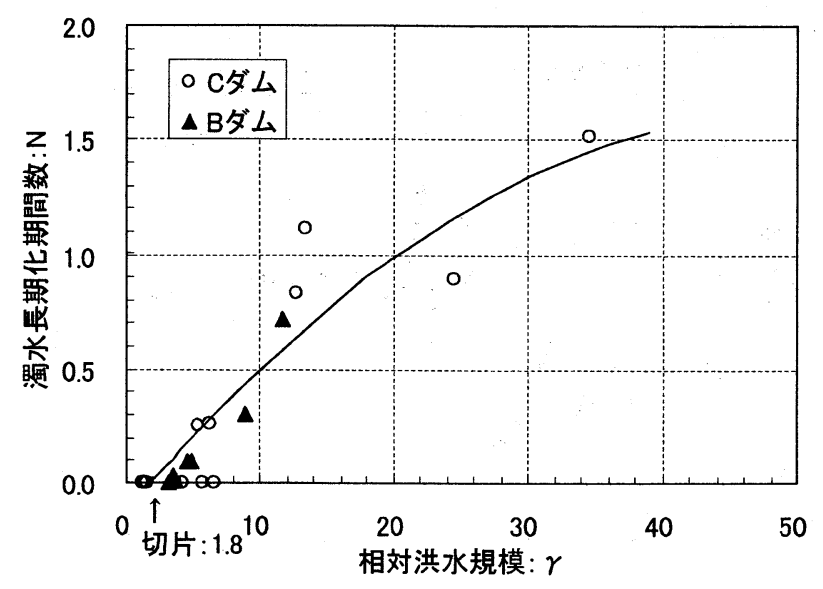

図-6 濁水長期化現象の生起条件

図を見ると，全量貯留する洪水ではほとんど放流 が行われないため, ダム湖が一種の沈砂池となり， 濁水長期化現象はあまり生じない。

洪水ピークが 2 回以上発生した場合は，濁水長期 化の日数が多少ばらつくが, 全量貯留する洪水を除 けば, 濁水長期化日数と洪水ピーク時間流量との間 には良い相関があるといえる．また，濁水長期化現 象は，洪水ピーク流量が約 $200 \mathrm{~m} 3 / \mathrm{s}$ を超える埸合に 見られる。

\section{（5）小規模出水におけるダム湖内濁水挙動}

図-5(1) D ダムにおける出水時と出水後の水温 · 濁度変化の一例である $(\beta=0.2)$. 眓から出水時の 濁水が中層を流下している様子が見られる．これは 濁水が水温躍層に沿って流入するためであり，濁質 のピーク層は躍層よりやや低い位置に存在する. 出 水後は表層放流が行われ，濁質が徐々に放流される ため, 水温躍層下に存在する濁質ピーク層の濁度は ダムサイトから上流に向かって低減していく.

\section{（6）中規模出水におけるダム湖内濁水挙動}

図-5(2)は，中規模出水 $(\beta=0.9)$ 時とその後の貯 水池内水温・濁度分布である.この出水では明確な 濁質のピーク層が見られず, 躍層より上層は一様に 高い濁度を示している. また, 出水後は, 濁質が貯 水池内に帯状に滞留している様子が見られる. 出水 後は, 洪水によって破壊された一次躍層が受熱期初 期と同様に再形成されるため, 取水による中間流が 形成され，このような現象が見られる．この濁質の ピーク層は濁水長期化の原因となる.

\section{4. 濁水長期化現象の発生条件と選択取水方法}

\section{（1）濁水長期化現象の発生条件}

濁水長期化現象とその発生条件や依存因子の関係
を求めることは，ダム運用及び濁水制御の観点から 重要である. 以下では, 2 つの無次元数を提案し, これらの関係の一般化を試行的に検討する.

3.で述べたように，水温躍層より上の水（以下， 温水層）が洪水による濁水と入れ替われば，濁水長 期化現象が発生する. その濁水長期化現象は濁質が 水温躍層以下に沈降するまで継続する. そこで, 濁 水長期化の指標として以下の無次元数を導入する.

濁水長期化期間数 $: \mathrm{N}=\mathrm{NC} \times \mathrm{W}_{\mathrm{s}} / \mathrm{HY}$

ここに, $\mathrm{NC}$ は濁水長期化日数 ( $\mathrm{NC}$ は濁水基準に よって当然変化するが，ここでは $25 \mathrm{mg} / \mathrm{l}$ を $\mathrm{SS}$ 基準 として用いる)， $W_{\mathrm{s}}$ は濁水長期化の原因となる微細 土砂の沈降速度（ここでは, 通過重量百分率 $10 \%$ に 対応する粒径: $\mathrm{d}_{10}$ より算定した), Hyは洪水前温水 層厚である。

すなわち, 濁水長期化に影響する微細土砂が躍層 下まで沈降する時間 $\left(\mathrm{Hy} / \mathrm{W}_{\mathrm{s}}\right)$ を用いて, 濁水長期 化日数を無次元化したものである.

一方，洪水規模の指標としては， $\beta$ が広く用いら れているが，3. (3)，(4)においてピーク流量も重要 なファクターであることを示した（ $\beta$ が同じでもだ らだら続く洪水に比較して，短期間のうちに終了す る洪水の方が濁り易い).そこで, 洪水規模の指標と して, 洪水ピーク流量を含めた以下の無次元数を導 入する。

相対洪水規模 : $\gamma=V_{F} / V_{Y} \times Q_{P} / Q_{\text {ave }}$

ここに，Qpは洪水ピーク流量，Qaveは洪水期間平 均流量, $V_{F}$ は洪水総流入量, $V_{Y}$ は洪水前の温水層容 量である. $\mathrm{V}_{\mathrm{F}} / \mathrm{V}_{\mathrm{Y}}$ は, 中小規模洪水の濁水現象に影 響する温水層容量を用いた $\beta$ と考えることができる。

定義した無次元数を用いて, 対象 2 ダムにおける 中小規模洪水と濁水長期化日数との関係を図-6に整 理した.ただし, 流量ピークが 2 回以上となる洪水 及び，全量貯留する洪水は除いてある.

図を見ると，無次元長期化期間数と無次元相対洪 水規模の間に相関関係が見られる. 図から相対洪水 規模 $\gamma$ が約 1.8 を越えると濁水長期化現象が生じて いる. つまり， $\gamma$ が 1.8 より小さい場合, 流入濁水 は温水層で希釈され, 濁水長期化現象はほとんど生 じないが， $\gamma$ が 1.8 以上となると温水層の希釈能力 が限界に達し，濁水長期化現象が生じる.

本研究は濁水長期化期間と洪水規模の定量的な関 係を試行的に求めたものであるが，検討対象ダムは 2 ダムであり，一般化には実測デー夕を含む他ダム の資料を更に収集する必要があることを付記する.

（2）中小規模出水における選択取水効果検討 明瞭な躍層が存在する場合の小規模出水（洪水後 も躍層が残存する）に対する濁水対策は，選択取水 が有効であると考えられる. 一方, 中規模出水の場 

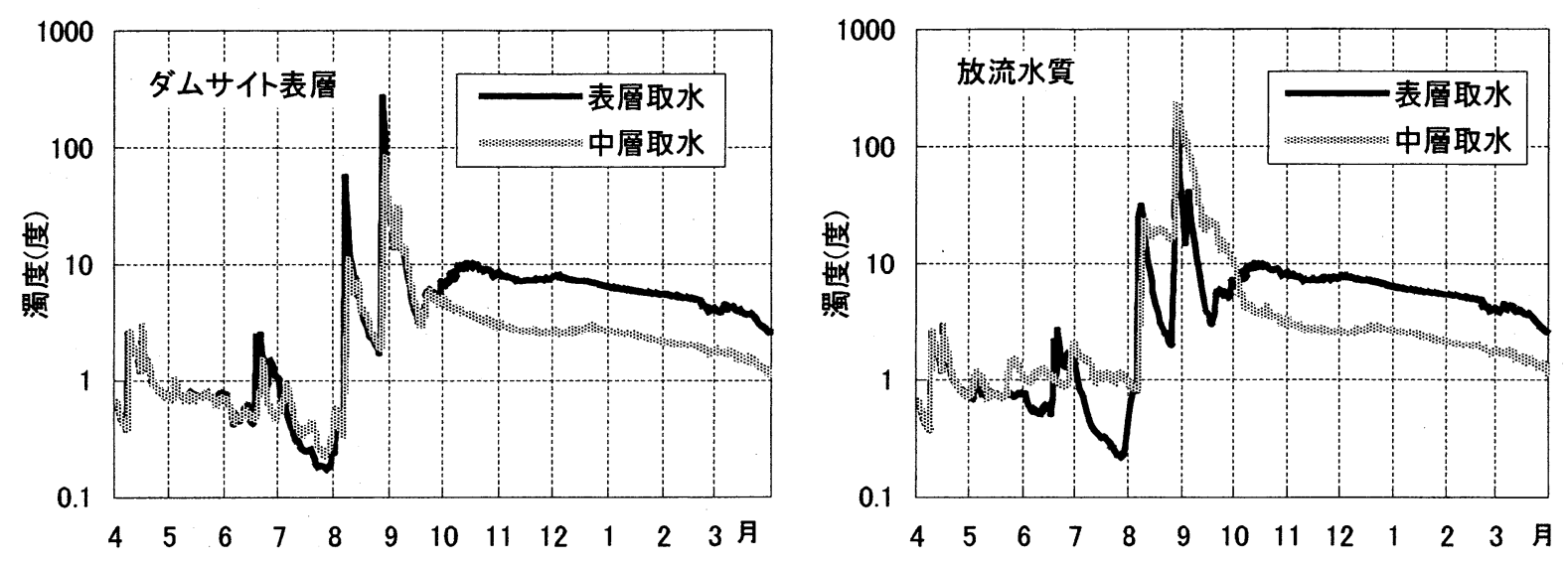

図-7 選択取水による濁水対策効果

合は，濁水が温水層の水と入れ替わり，濁水長期化 現象が発生する.

4.(1)で述べたように, 流入濁水の特性は相対洪 水規慔 $\gamma$ によって変化する. したがって, 選択取水 設備を有効に利用し，水温躍層を低下させることに よって相対洪水規模を小さくすれば，濁水長期化現 象をある程度制御出来るものと考えられる．期待さ れる効果は, 以下の 2 つである。

(1)温水層容量が大きくなり, $\gamma=1.8$ となる洪水ピー ク流量, あるいは洪水流入総量が大きくなる.つ まり,濁水長期化現象が生じる流量が大きくなる. (2)コンジット部に洪水吐きがある場合, 躍層位置を 洪水吐き敷高と合わせれば, 濁水の早期排除が可 能となり, $\gamma>1.8$ のような洪水でも濁水長期化を 軽減できる.

ここでは, $\mathrm{E}$ ダムを対象に常時表層取水と常時中 層取水を行った場合の濁水長期化現象の発生程度を 図-7に比較する.ちなみに，9月の洪水による $\gamma$ は 前者で 26.3 , 後者で 3.3 であった. 中層取水を行っ た場合は, 洪水時と直後に放流濁度が高くなってい るが，10月以後, 貯水池が対流期に入るとダムサイ 卜表層, 放流とも表層取水と比較して濁度がほぼ半 減していることが分かる (E ダムの目標濁度は 5 度 であるので、非常に効果がある).これは，中層取水 を行った結果, 水温躍層が低下し, 相対洪水規模が 小さくなった効果と洪水時濁質の早期排除効果のた めである.

\section{5.まとめ}

本報告は濁水長期化現象とその要因を数值シミ ユレーション結果から試行的に検討したものである. 結果は, 以下の通りである.
(1)濁水長期化現象は夕゙ム成層状況，洪水規模と生起 時期,濁質の粒径等が複雑に関連した現象であり, 濁水長期化日数はこれらに大きく右右される. 本 検討では, 相対洪水規模 $\gamma$ をその発生程度を示す 指標として提案した。

(2)選択取水設備を用いて水温躍層を低下させること よって, 濁水長期化現象の生起流量を大きくする ことが可能である.また，コンジット部の放流設 備とあわせて, 濁質の早期排除が可能となり, 濁 水長期化現象を軽減できる.

(3)成層が破壊されるような大規模洪水に対しては， 選択取水設備の機能を期待することは出来ない. したがって，選択取水の限界についても認識する 必要がある.

\section{参考文献}

1）安芸周一, 白砂孝夫: 貯水池流動形態のシミュレーシ ヨンの解析その 1 , 発電水力, NO.134, pp.53-66, 1975.

2）森北佳昭, 天野邦彦: 貯水池水質の予測・評価モデル に関する研究, 土木研究所報告, 第 182 号-1, 1991.

3) Chen. F.Y., Yoshida. N, Sekine. H, Hotta. T, and Murata. K.: A prediction method and conservation measures of water quality in dam reservoirs, Proceedings of the Second International Summer Symposium, JSCE, pp.397-400, 2000.

4）松尾直規，山田正人，宗宮功: 貯水池上流端における流 動特性と淡水赤潮現象との関係, 水工学論文集, 第 40 巻, pp.575-581, 1996.

5）堀田哲夫, 金内剛, 東海林光: ダム貯水池での渴水濁水 現象と貯砂ダムによる対策効果について，河川技術論 文集, 第 7 巻, pp.209-214, 2001. 